\title{
HATÁRON ÁTNYÚLÓ INGÁZÁS A SZLOVÁK- MAGYAR HATÁRTÉRSÉGBEN
}

\author{
(Transborder Commuting on the Slovakian-Hungarian Border \\ Region)
}

\section{HARDI TAMÁS - LAMPL ZSUZSANNA}

Kulcsszavak:

ingázás határ munkaügyi körzet munkaerổpiac

Tanulmányunk a határon átnyúló ingázást vizsgálja. Egyrészt el kivánja különiteni az államon belulli ingázástól, valamint a nemzetközi munkaügyi migrációtól egyaránt. Kitérïnk az ingázás helyi munkaerõpiacra gyakorolt hatására, majd empirikus adatok alapján bemutatjuk a szlovák-magyar határtérségben zajló folyamatokat.

\section{Bevezetö}

Tanulmányunkban a határtérségekben kialakuló, határon átnyúló mozgások egy válfajával, az államhatárt átlépő, napi ingázással kívánunk foglalkozni. A jelenségre vonatkoztatott megállapításainkat empirikus adatokkal támasztjuk alá, amelyeket a magyar-szlovák határon szereztünk az elmúlt években. Fő kérdésünk, hogy hol, milyen intenzitással alakul(hat) ki határon átnyúló ingázás, mi segíti eló, mi gátolja a jelenséget, $s$ milyen hatást gyakorol a határtérség gazdaságára és társadalmára. Kutatásaink érdekes módon világítanak rá az államhatár fetisizált szerepére, hiszen a két ország közötti és a hármashatár térségben, a nyugati határ esetében az elmúlt 15-20 év távlatában az eltérő ideológiai-politikai rendszerek elzárt határaitól a teljesen liberalizált schengeni belső határokig az államhatár típusok valamennyi válfaja létezett.

A neoliberális felfogás egyszerúen egy akadálynak látja a határt a munkaerő és a tőke mozgása elött (Krakover 1997; Niebuhr-Stiller 2002). Azonban tapasztalhatjuk azt is, hogy nem egyszerüen az államhatár jelensége az, ami a munkaerő mozgását akadályozza, vagy módosítja annak természetes irányait. Az államhatár csupán egy adminisztratív megjelenítője a nemzetállami rendszerek térbeli érvényesülésének. Napjainkra a határ elválasztó funkciója jelentős mértékben leépült vizsgálati térségünkben. Magyarország, Ausztria és Szlovákia egyaránt a schengeni övezet tagjai, tehát közös határaik fizikai értelemben nem jelentenek akadályt a mozgások előtt. Adminisztratív szempontból ugyan Ausztria állít még korlátokat a szlovák és magyar munkavállalók bizonyos szegmensei előtt, de várható ezek leépülése is, miközben a magyar-szlovák munkaeró-áramlás lényegében szabadnak tekinthető. 
Az államhatár nyitása azonban nem általában a mozgások intenzitásának növekedését hozza, hanem a gazdasági szereplök és a lakosság egyes csoportjainak mozgását bizonyos irányokba. A mozgások irányai és intenzitása eltér a nemzetállami területen belüli mozgások irányától és intenzitásától. Tehát a „szabad határ” átlépése elött is adódhatnak akadályok, ugyanakkor egyes csoportok számára előnyöket is jelenthet a határ másik oldala a hazai területekhez képest (Hardi 2005).

Megállapíthatjuk, hogy határtérségeink számára a határok kinyitása egyszerüen a határok/határtérségek funkcióváltását hozta: eddig az elválasztó funkció volt a hangsúlyos, míg jelenleg az eltérỏ rendszereket összekötő szerep kerül elötérbe annak minden negatív vagy pozitív hozadékával együtt. Ezek a nemzetállami eltérések - úgy tünik - hosszabb távon fennmaradnak, így a határtérségek sajátosságai, különleges gazdasági-társadalmi szerepe is.

Tanulmányunk empirikus alapjait két kérdöives felmérés adja. Az első, amelyet a Tér és Társadalom jelenlegi számának több tanulmánya is felhasznál, egy reprezentatív lakossági felmérés a határ mindkét oldalán. A másikat a Fórum Kisebbségkutató Intézet készítette az MTA RKK NYUTI-val együttmüködve. Ez utóbbi felmérés keretében 500 szlovákiai munkavállalót kérdeztünk meg, akik Magyarországra ingáznak.

A szlovákiai munkavállalók magyarországi alkalmazása az EU-csatlakozás előtt is létezett, már az 1990-es évek végétöl sokan jártak át a határhoz közeli munkahelyekre. Ezt elösegítette a két állam megállapodása, a közös nyelv és kultúra, s a határhoz közeli szlovák járások magas munkanélkülisége. A csatlakozás utáni időben talán a leggyorsabban növekvő, legintenzívebb határon átnyúló folyamattá vált az országban, így komoly figyelmet is keltett. 2004-2005-ben az ingázók számát 30 ezer körülire becsültük. Napjainkra a kép részben megváltozott: Szlovákia gyors gazdasági növekedésének köszönhetően a bérek kezdenek kiegyenlítödni, sőt egyes ágazatokban és az árfolyam-hatásoknak, az alacsonyabb adóelvonásnak köszönhetően szlovák oldalon néhol még magasabbak is. (Igaz, tapasztalataink szerint az alacsonyabban kvalifikált tevékenységek esetében Magyarországon magasabbak a bérek - elsősorban a magasabb minimálbérnek köszönhetően, miközben az alacsony minimálbér és az egykulcsos adórendszer következtében Szlovákiában nagyobbak a bérek közötti különbségek reginálisan és beosztástól, munkahelytöl függően.)

Ugyanakkor a legutóbbi években új jelenségekre is felfigyelhettünk: Pozsony agglomerációját kiterjesztette Magyarországra és Ausztriára; sok pozsonyi család vásárolt ingatlant, s költözött a közeli, de szomszédos országban lévő településekre. Ök is lényegében a határon át ingázók számát gyarapítják, mivel munkahelyüket, iskolájukat temrészetesen megtartották a szlovák fövárosban. A határ keleti részén pedig megindult a magyarországi szakemberek ingázása szlovákiai munkahelyekre. Ez ugyan még kisebb volumenü, mint a dunai szakaszon a Szlovákiából Magyarországra áramlóké, de vélhetően növekvő jelenséggel van dolgunk. 
Hardi Tamás - Lampl Zsuzsanna: Határon átnyúló ingázás a szlovák-magyar határtérségben.

Tér és Társadalom, 22. 2008. 3. 109-126. p.

TÉT XXII. évf. 2008 - 3

Határon átnyúló ingázás ...

111

\section{Az államhatár és a munkavállalás}

\section{A határon átnyúló ingázás sajátosságai}

Az ingázó munkavállalás az indusztriális társadalom egyik alapvető jelensége. A közlekedési lehetőségek javulásával lehetỏvé vált, hogy a munkahely és a lakóhely térben különváljon egymástól. A munkahelyek térbeli koncentrációjának erösödésével egyre nagyobb lett a jelentősége az ingázó forgalomnak, melynek fö iránya a vidék és város között alakult ki.

Ingázónak nevezhetjük azokat a munkavállalókat, akiknek munkahelye és lakóhelye eltérỏ településeken található, s mozgásuk napi vagy heti rendszerességgel valósul meg a két pont között. Kutatási eredmények azt mutatják, hogy az ingázó forgalom nagysága függ a megközelítési időtöl, s egy-egy munkahelyre ingázók nagy hányada a 60 perces zónán belül mozog. Jellemző, hogy minél nagyobb egy munkahelyeket kínáló központ, annál nagyobb a munkaügyi vonzáskörzete, annál hosszabb lesz az ingázók által az utazással eltöltött átlagos idő. A klasszikus ingázás motivációi között elsősorban a munkahely, mint ingázási cél szerepel, tehát az ingázó saját lakóhelyén nem, vagy csak nagy kompromisszumok árán juthatna munkához. Így szükségszerü, hogy naponta egy másik településre járjon dolgozni.

$\mathrm{Az}$ iskolásnak tűnő bevezető szükségességét az indokolja, hogy rávilágítsunk arra, hogy egy államon belüli térben az ingázás irányát és távolságát a térségen belül a munkaeröpiacon tapasztalható kínálat-kereslet és a közlekedési lehetőségek befolyásolják. Ettől eltér egy határ menti térség munkaerőpiacának helyzete. Az államhatár módosítja az ingázás irányára és távolságára ható tényezőket. Ez a módosulás a határ funkcióitól függően különböző mértékü és minőségü lehet. Mik lehetnek ezek a hatások? Két jellegzetes tényezö csoportot különböztethetünk meg.

- Térszerkezeti hatások. A határ két oldalán elhelyezkedő területek közötti erös térszerkezeti kapcsolatok az államhatár torzitó hatásait csökkentik, s egy térbeli természetes rend helyreállásának irányába hatnak. Ezek: a határokon ảtnyúló létező vagy potenciális vonzáskörzetek, gazdasági fejlödési tengelyek, fejlett közlekedési vonalak. Ugyanakkor a periférikus területek találkozása, a határ nehéz átjárhatósága, a kevés átvezető közlekedési pálya akadályozhatja a határon átnyúló ingázás megjelenését, fejlődését.

- A határ menti térségek ingázó forgalmára a legtartósabb hatást a térszerkezeti szükségszerüségek gyakorolják. Amennyiben a határ valamelyik oldalán gazdaságilag növekvő centrumtérség található, akkor annak a további növekedéshez ủjabb és újabb erőforrásokra van szüksége, beleértve a szabad munkaeröt is. A határ menti centrumtérség hamar kimeríti saját erőforrásait, hiszen vonzáskörzete csonka, összehasonlítva egy nem határ menti központtal, $\mathrm{s}$ a növekedéséhez szükséges újabb erőforrások biztosítására a határ másik oldala jöhet számításba. A történelmileg kialakult jellemző térszerkezeti irányok és térségek általában a mai államhatároktól függetlenül alakultak ki. Így a gazdaságilag fejlett tenge- 
lyek, a foglalkoztató központok potenciális vonzáskörzetei átterjednek az államhatárokon. Így van ez különösen a Kárpát-medencében, ahol a jelentősebb városok nagy része államhatár mellett található, így vonzáskörzete torz, potenciális munkaerő-bázisának csak egy részét használhatja ki. A szabad munkaerő áramlás hozzásegítheti ahhoz, hogy gazdasági potenciáljának megfelelö munkaügyi vonzáskörzetre tegyen szert. Ezt a lehetőséget használják ki a szlovák-magyar határ dunai szakaszának városai (Esztergom, Komárom, Győr), a szlovák oldal foglalkoztató centrumai messzebb találhatók a határ menti településektől, mint a magyarországi városok. Hasonló elv alapján (is) jöhet számításba az osztrákmagyar viszonylatban Bécs, mint ingázási központ.

- Hasonlóképpen az ingázásra nézve előnyöket biztosít a határon túlnyúló nemzetiségi szállásterület (mint pl. a magyarság Dél-Szlovákiában), mivel a munkavállalás kulturális, nyelvi akadályai nem állnak fenn.

- A határon átnyúló ingázás mértékére hatással vannak a határtérség közlekedési viszonyai. Mint a bevezetőben emlitettük, az ingázás nagyobb részt a hatvan perces megközelíthetőségen belül zajlik. Nincs ez másként a határtérségekben sem. Itt a közlekedési időhöz azonban hozzájárul még a határátlépéshez szükséges időtartam. Fontos szemponttá válik a határátkelők sủrúsége, nyitvatartási ideje, megközelíthetősége. Így a határon átnyúló (elsősorban napi) ingázás kimondottan a határ mentén, vagy a határt átszelő közlekedési tengelyek mentén élók számára adott lehetőség.

- Az eltérỏ gazdasági rendszerek találkozása olyan térbeli mozgási, ingázási folyamatokat indíthat el, amelyek alapvetően eltérhetnek a „hagyományos”, országon, rendszeren belüli ingázási mozgásoktól. Hatásuk ugyanakkor kevésbé tartós, $\mathrm{s}$ gyors változások is bekövetkezhetnek. Az eltérö rendszerek találkozása legkorábban és legszembetünöbben az árak és bérek különbségében nyilvánul meg, amelyek a munkaerő mozgására a legerősebb hatást gyakorolják. Mindemellett azonban a mozgás irányára hatással vannak más rendszerbeli különbségek is: a munkakörülmények, szociális ellátások különbségei. Fontos szempont lehet, hogy a határ menti térség munkaerőpiacán bizonyos szegmensekben hiány mutatkozik: szakképzettség szerint, életkor szerint stb., így ezeket a hiányokat a másik oldalról tudja csak pótolni a térség. Ez a probléma hatványozottan jelentkezik az osztrák-magyar határtérségben: az osztrák oldal szakember elszívó hatása olyan mértékben érvényesül, hogy a magyar régióban több szakmában jelentős munkaerő hiány alakult ki. Érdekes lehetőség, hogy egy osztrák-szlovákmagyar közös regionális munkaügyi stratégia felvázolásával ezt a hiányt a magyar oldal pótolhatná Szlovákiából is. Az adók, járulékok, jogi lehetőségek különbségei szintén erősíthetik a határon átnyưló ingázást. Szlovákiảban, pl. a munkaerő kölcsönző cégek szabad müködése lehetővé teszi, hogy a magyarországi alkalmazó nagyvállalatokkal szerződést kössenek, s mindig a megfelelő létszámú dolgozót ingáztassák Magyarországra. Így a hazai cégek egy-egy nagyobb megrendelés esetén rugalmasabban jutnak több dolgozóhoz, $\mathrm{s}$ a végén a leépítésük is „problémamentes”. Mindenesetre ezek a különbségek időlegesen 
Hardi Tamás - Lampl Zsuzsanna: Határon átnyúló ingázás a szlovák-magyar határtérségben.

Tér és Társadalom, 22. 2008. 3. 109-126. p.

TÉT XXII. évf. 2008 『 3

Határon átnyúló ingázás ...

113

erősebbek lehetnek a térszerkezeti meghatározottságoknál, akár azokkal szemben is hathatnak. Az osztrák-magyar határ esetében a jövedelmi különbségek miatt gyakran a hagyományos városokból (Szombathely, Sopron) ingáznak a munkavállalók a burgenlandi vidéki térségekbe, kisvárosokba.

Mint láttuk tehát, az államhatár menti területek munkaerőpiacára jelentős hatást gyakorolhat az államhatár jelenléte. $\mathrm{E}$ két hatás erősítheti, $\mathrm{s}$ gyengítheti is egymást. A rendszerbeli különbségek ráerỏsíthetnek egy térszerkezeti adottság hatására, vagy ki is olthatják azt. Az osztrák-magyar határ menti munkavállalás mozgási irányaiban egyértelmüen a két rendszer közötti eltérés a fö alakító tényező, a földrajzi térszerkezet hatásai csak másodlagosan érvényesülnek, a munkavállalás célterületei elszórtan helyezkednek el, kicsi a földrajzi koncentráció. Ezzel szemben a szlovákmagyar határ esetében a térszerkezeti hatások történelmi léptékben meghatározzák az ingázási irányokat, itt az átjárás jellemzően néhány központra koncentrálódik.

\section{A határon átnyúló ingázás és a helyi munkaeröpiac}

A határon átnyúló ingázás érdekességét az adja, hogy jogilag egy nemzetközi migráció valósul meg, de zömében lokális körülmények között. A munkaügyi adatgyüjtés általában külföldiek munkavállalására vonatkozik, $s$ hasonlóképpen a munkavállalás szabályozása is. Maga a jelenség azonban eltér a hagyományos „,külföldi” munkavállalástól, hiszen a munkavállalók életvitelszerủen a szomszédos államban élnek, míg munkahelyük a másik állam területén van. Ez a szituáció kiemeli ezt a munkavállalói kört a külföldiek közül, hiszen helyzetük sajátos, ami egy sor kérdést vet fel: a napi közlekedés megszervezésétől a közszolgáltatások igénybevételén át az adózásig és a jövedelem átváltásáig számos különleges helyzet merülhet fel.

$\mathrm{Az}$ általunk vizsgált jelenséget tehát el kell választanunk az általános, nemzetközi térben jelentkező munkavállalástól, mivel az tipikusan egy határon átnyúló munkaügyi térséget, vonzáskörzetet érint. Tehát egy olyan jelenséggel van dolgunk, amelyet a nemzetállami téren belül már ismerünk, azonban a piac törvényeinek engedve, $\mathrm{s}$ a felmerülő lehetóségeket (a határok átjárhatóságát, az intézményi integrációt, $\mathrm{s}$ a szomszédos határtérség széles értelemben vett elérhetőségének javulását) kihasználva egyes lokális munkaerő-piaci térségek átnyúlnak a közeli államhatáron, s kapcsolataik egy részét kiépítik annak másik oldalán is.

Ez ugyanakkor nem jelenti azt, hogy az egyik állam munkaerö-piaci térsége egy az egyben terjed ki a szomszédos határ menti területekre. Az uniós integráció ellenére az általunk vizsgált lokális szinten az állam szabályozó, fiskális stb. funkciója erős. Márpedig az állam (általában) hivatalosan nem tesz kivételt a szomszédos állam polgárai között, pont az állami szintü integrációnak köszönhetően nem alkalmazhat más szabályozást a határ mentén élö külföldiek fogadására, mint a távolabb élőkére. A „határtalan” világ jelenleg optimista elképzelésnek tünik, mivel a nemzetközi munkaügyi migráció egy nemzetállami keretekből építkező térben valósul 
meg. A nemzetállami határ kevésbé áteresztő jellegủ a munkaerő, mint a töke vagy a javak elött (Amin 1996).

Tehát a határon átnyúló munkerö-piaci térségünk sajátossága, hogy a belföldi mellett olyan kapcsolatokra is kiterjed, amelyek lokális, térségi szintüek, de a nemzetközi kapcsolatok makro-szintủ szabályai vonatkoznak rá. Ugyanakkor a térségen belül eltérő állami szabályozási, társadalmi, gazdasági, közigazgatási, közszolgáltatási rendszerek találkoznak. Ezek még az uniós integráció ellenére is megtartják különbözőségeiket. Ezek a különbségek elönyöket is jelenthetnek a térség számára (pl. az adórendszer eltérései), de gyengíthetik is a térségen belüli áramlásokat, kapcsolatokat (pl. társadalombiztosítás eltérései, közigazgatás rugalmatlansága).

A nemzetközi migráció és a helyi munkaerőpiac viszonya többarcú lehet. Egyes esetekben a nemzetközi beáramlást a gazdasági növekedés egyik motorjának tartják, mint pl. az USA esetében a kilencvenes években (Aydemir-Borjas 2006; Shuttleworth 2007), azonban, különösen a képzetlen s rosszul fizetett tevékenységek kapcsán a bevándorló munkaerő rovására írják a helyi munkaerőpiacok egyensúlyának felborulását, polarizációját. Ezek a tanulmányok azonban zömében a nagyvárosi, világvárosi kategóriákkal foglalkoznak, miközben a külföldi munkaeró gyakran a vidéki térségekben tünik fel a nehezen betölthetö, rosszul fizetett állásokban.

A határtérségen belüli ingázás - tapasztalataink szerint - sokkal inkább igazodik a helyi munkaerőpiac kereslet-kínálati tradícióihoz, mint a nemzetközi migráció általában, így inkább erőforrást, mint a lokális munkaeröpiac egyensúlyát veszélyeztetô túlkínálatot jelent. Ők a helyi munkaerőpiac meglévő keresletére építve lépik át a határt, amennyiben nem találnak munkát, vagy megszünik a munkahelyük, azonnal visszatérnek a másik állam területére, hiszen ott van a lakásuk.

A határon túlra kiterjeszthetô ingázási vonzásterület egy település vagy agglomeráció gazdasága számára növekedési lehetőséget teremt, egy másik állam költségén kiképzett munkaeró és tudás felhasználását, miközben a munkaerővel kapcsolatos esetleges problémák (munkanélküliség, szociális problémák) a szomszédos térségben maradnak, mivel a foglalkoztatottak lakhelye ott található. Az ingázó munkavállalók megitélése is más általában, mint a távolról jövő nemzetközi migránsoké, közelebb áll a helyi alkalmazottakéhoz.

A térségi jellegú megközelítés azért is fontos, mert hasonlóan a belföldi kapcsolatokhoz, a határon átnyúló kapcsolatok sem feltétlenül egyirányúak, hanem különbözỏ csoportok (képzettségi szint, szakma stb. szerint) különböző irányba mozoghatnak.

\section{Az ingázó munkavállalás a szlovák-magyar határtérségben}

Az ezredforduló óta az egyik legdinamikusabban fejlődő határon átnyúló mozgás az ingázó munkavállalás. Ennek kapcsán több felmérés is készült, uniós program keretei között megindult a munkaügyi régió definiálása, kutatása (Hárs 2006). Látni kell azonban, hogy a kölcsönös munkavállalás már hagyományosan létezik a térségben. Az ipari fejlettség tengelyei, valamint a nyelvi-kulturális akadályok hiánya 
Hardi Tamás - Lampl Zsuzsanna: Határon átnyúló ingázás a szlovák-magyar határtérségben. Tér és Társadalom, 22. 2008. 3. 109-126. p.

TÉT XXII. évf. 2008 — 3

Határon átnyúló ingázás ...

115

miatt már a szocialista időszakban is létezett, de a rendszerváltás körüli idöszak gazdasági hanyatlása miatt átmenetileg megszünt a határon átnyúló kölcsönös munkavállalás. A stagnálás után, 1999 óta gyorsan növekedett a Szlovákiából Magyarországra átjáró munkavállalók száma. A nyugati határtérségben szlovák oldalon magasabb munkanélküliséggel találkozunk, mint Magyarországon, $\mathrm{s}$ a határ közelében jelentős ipari központok helyezkednek el (Györ, Komárom, AlmásfüzitöEsztergom-Dorog tengely, Tatabánya, sőt Mór), amelyek a helyi munkaerő kapacitást már kimerítették. A rendszeres ingázást megnehezíti ugyanakkor a hidak csekély száma. Mosonmagyaróvár, Györ és Komárom kapcsolatainak jelentős indikátorai voltak a Duna-hidak, (s ez a szerep jutott az újjá épített Mária Valéria-hídnak is Esztergomban és környékén). A múlt század hetvenes éveitől jelentős szlovákiai létszámot alkalmazó Almásfüzitő-Lábatlan-Nyergesújfalu térség esetében viszont hajóval oldották meg az ingázást, Esztergomban korábban komppal. Ez a közlekedési forma viszont bizonytalan, nagymértékben függ az időjárástól, $\mathrm{s}$ az évszakos tényezőktől (jégzajlás, árvizek, kisvizek). 1999-től az ingázás fejlődését a két ország közötti keretegyezmény is segítette, ami lehetővé tette, hogy mind többen vállalhassanak munkát a másik országban (értelemszerüen ez Magyarországot jelentette elsősorban), sőt, az uniós csatlakozás elötti évben olyan bőven szabta meg a kereteket, hogy a gyakorlatban már ekkor megszünt a korlát az átjárás előtt. 2004 májusa tehát nem érte felkészületlenül a munkaerőpiacot. 2005-ben a Magyarországon munkát vállaló szlovák állampolgárok számát már 30 ezer fő körül becsülték. Pontos számokat mind a mai napig nem ismerünk, mivel a munkavállalás adminisztrációja az uniós csatlakozással megszünt, a foglalkoztatónak kötelező ugyan bejelenteni a külföldi munkavállalót a munkaügyi szerveknél, azonban ennek elmulasztása különösebb szankcióval nem jár, tehát a bejelentés is bizonytalan. Az uniós csatlakozással mindenképpen ugrásszerúen megnőtt az ingázók száma. Az EUcsatlakozás óta Szlovákia egy nagyon gyors gazdasági fejlődést él át. Ez a tény természetesen kihatással van az ottani munkaerőpiacra is. Így a nyugati szakaszon is csökkenöben van az átjárók száma, valószínüleg egy egészséges szinten stabilizálódni fog, s azok fogják a magyarországi munkahelyeket választani, akik számára a hazai város térbeli előnyt jelent. Ugyanakkor tapasztalható, hogy megindult az ellentétes irányú folyamat is. A hazai munkavállalókat szlovák vállalkozások csábítják át a határon. Elsősorban a strukturális problémák megoldására, vagyis a szakember hiány leküzdésére keresnek Magyarországon szakmunkásokat. Így pl. Komárom-Esztergom megyéből még Nagyszombatba is járnak munkások, akiket az autóipar foglalkoztat. A legutóbbi idők újdonsága, hogy a keleti, lényegesen magasabb munkanélküliséggel küzdő területeken is tapasztalható, hogy szlovákiai vállalkozók Magyarországon keresnek munkaerőt. Nyilván itt is a szakmunka igény dominál, különösen az olyan határ menti, periférikus térségekben, ahonnan a szakmunkás réteg már javarészt elvándorolt. A gazdasági fejlődés mindenképpen érdekes határon átnyúló mozgásokat produkál.

Szlovákiában, a határ nyugati szakaszán, a határhoz közeli járásokban az országos átlag körül mozog a munkanélküliség (10\% körüli), illetve azt némileg meghaladja. 
Térképünkhöz kerületi szintü adatok álltak rendelkezésünkre, de ezek az adatok is kiválóan mutatják a nyugat-kelet lejtöt ( 1 . ábra). Természetesen a kerületeken belül járási szinten, $\mathrm{s}$ a járásokon belül is jelentős eltérések lehetnek a munkanélküliség tekintetében. Az Érsekújvári járás esetében például a határhoz közeli területeken a munkanélküliség lényegesen meghaladja az országos átlagot. A keleti szakaszon pedig a határ menti periférikus területek munkaerö-piaci helyzete sokhelyütt tragikusnak mondható. Mindehhez hozzájárul, hogy ezeket a területeket a képzettebb lakosok elvándorlása is sújtja, így fel kell készülni arra, hogy ezekben a térségekben még a kisebb, megtelepülő vállalkozások számára is csak a határ két oldala közösen tud megfelelő szakember létszámot biztosítani. Így ezekben a térségekben a gazdasági fejlődést közvetlenül szolgálhatja a kis, összekötő utak helyreállítása.

\section{1. ÁBRA}

A határ menti NUTS3 területi egységek munkanélküliségi rátája a Kárpát-medencében

(Unemployment-rate of NUT3 Level Border Regions in Carpathian Basin)

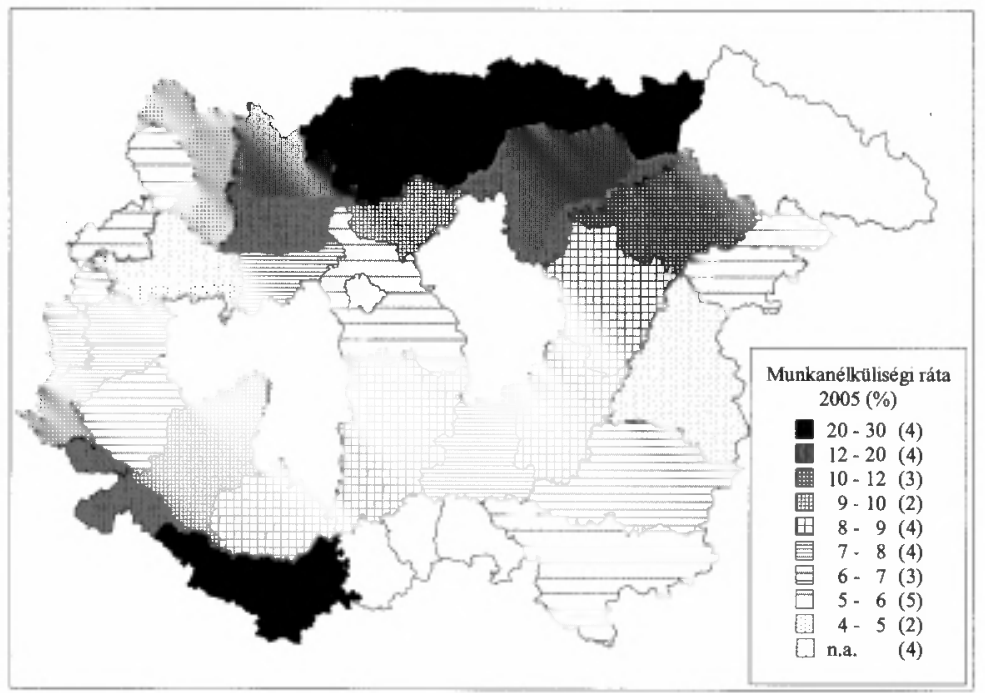

Forrás: Eurostat és nemzeti statisztikai hivatalok (CRO) adatai alapján szerkesztette Hardi Tamás.

A Duna magyar oldalán kedvezőbb a kép a határ teljes hosszában. A nyugati szakaszon magas az ipari foglalkoztatás. A kilencvenes évek elején a korábban itt múködő, sok alkalmazottat foglalkoztató üzemek (pl. timföldgyártás, cementgyártás, mủanyagipar) leálltak vagy csökkentették létszámukat, így az országos átlagot meghaladó munkanélküliségi ráták alakultak ki a térségben. Az ezredfordulóra a tendencia megváltozott, Esztergom és a komáromi Ipari Park munkaerö-szükséglete következtében a ráták ismét az országos átlag alatt maradnak. Ezzel szemben keleten hazai viszonylatban magas, de a szlovák oldalénál alacsonyabb a munkanélküliek aránya. 
Hardi Tamás - Lampl Zsuzsanna: Határon átnyúló ingázás a szlovák-magyar határtérségben. Tér és Társadalom, 22. 2008. 3. 109-126. p.

TÉT XXII. évf. 2008 @ 3

Határon átnyúló ingázás ...

117

Mindezek fényében érdekes jelenség, hogy a keleti határszakaszon napjainkban megindult a Magyarországról Szlovákiába ingázás. A Kassa környékén alakuló vállalkozások a magas munkanélküliség ellenére keresik a szakképzett munkaerőt, $\mathrm{s}$ így a magyar határ menti területeket is célba veszik. A jövöt mutatja a 2. ábra, amely lakossági kérdőívünk eredményeiből született. A lakosok véleményét kértük arról, hogy a szomszéd országban történő munkavállalás szempontjából elönyösnek érzik-e a határ mentén elhelyezkedő lakhelyeiket? Érdekesen kiemelkedik a dunai térség, amely a leginkább érintett a határon átnyúló ingázásban (az ingázók mintegy harmada mozog ebben az övezetben). Itt a szlovák oldali válaszadók értékelték magasan a munkavállalás lehetöségét. Még érdekesebb a keleti határszakasz. A hegyvidéki övezetben mindkét oldalon kevés a munkahely, így ott az ingázás lehetöségét viszonylag alacsonyan értékelték, viszont Kassa vonzáskörzetében kiegyenlitődnek a várakozások, a magyar oldali válaszadók is nagyobb arányban érezték elỏnynek határ menti lakhelyeiket: számítanak a szlovák növekedés által kínált munkahelyekre!

\section{2. ÁBRA}

A szomszédos országhoz való közelség inkább elönyökkel vagy inkább hátrányokkal jár az Ön és családja életében a munkalehetőség tekintetében?

(Does the Proximity to Neighbour Country Mean Rather Advantage or Disadvantage in Your and Family Life Respect of Employment Opportunity?)

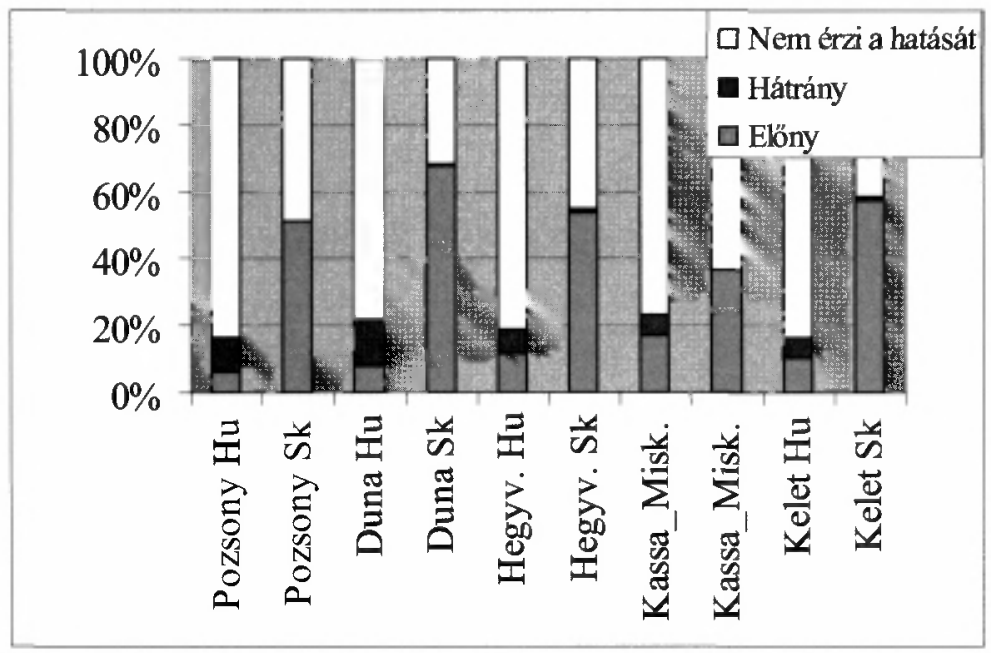

Forrás: Lakossági kérdỏívek (2008).

\section{A munkaügyi kapcsolatok története}

A kölcsönös munkavállalás története a hetvenes évekre vezethető vissza, amikor már alkalmaztak Pozsonyban, Gyôrben, Komáromban és Nyergesújfalun a határ másik oldaláról érkezett munkavállalókat. A két állam, Csehszlovákia és Magyarország 1985-ben írt alá nemzetközi egyezményt a kölcsönös munkavállalásról 
„Egyezmény a Magyar Népköztársaság Kormánya, valamint a Csehszlovák Szocialista Köztársaság Kormánya között a magyar és a csehszlovák állampolgárok határ menti területeken történő kölcsönös foglalkoztatásáról" címmel, amelyet minisztertanácsi rendelettel hirdettek ki. Az egyezmény elöírta, hogy évenként határozzák meg a következő évre szóló létszámkeretet. Ebben az időszakban jelentős volt mind a két irányba az ingázás. Mosonmagyaróvár térségével szemben Pozsony helyezkedik el, amely a nyolcvanas években mint a Csehszlovákián belüli Szlovák Szocialista Köztársaság székhelye jelentős gazdasági-ipari fejlődésen ment keresztül. Így Mosonmagyaróvárról és környékéről számos munkavállaló járt át a pozsonyi üzemekbe, $\mathrm{s}$ a jelentős méretú építkezések is magyar segédlettel történtek (a Petrezalka városrész építésében, valamint a Duna-híd építésében vettek részt magyar - győrivállalatok és szakemberek). Györtỏl kezdődően viszont általában magyar oldalon jelentkezik a magasabb gazdasági fejlettség és a jelentősebb munkaerőigény. Győrben föleg a textiliparban helyezkedtek el a határ másik oldaláról érkezők.

Arányait tekintve Komárom helyzete kiemelkedő. A kettős város tulajdonképpen egy egységnek tekinthető, melynek történelmi központja (maga a történelmi Komárom) az északi, szlovákiai parton helyezkedik el. A két várost voltaképpen csak a határ, illetve az államhatárt alkotó Duna választja el egymástól. Az egymásrautaltság megjelent a kölcsönös munkavállalásban is. Itt mindegyik oldalon dolgoztak a másik ország állampolgárai is. A Komáromi Lengyár 200-250 föt - föleg nőket alkalmazott Révkomáromból és környékéről, míg Magyarországról elsősorban a Hajógyárba jártak át férfiak dolgozni.

A Komáromtól Almásfüzitőn át Esztergomig húzódó fejlődési tengely jelentős munkaerő felvevő volt már a nyolcvanas években is. Elsősorban a Timföldgyárban, de a többi üzemben is találtak munkát a határ másik oldaláról érkezők.

\section{Ingázó munkavállalók az empirikus adatok tükrében}

Arról, hogy a szlovák állampolgárok közül hányan dolgoznak Magyarországon, nincsenek pontos adatok. A becslések 30 ezer személyrỏl szólnak. Ebben a számban benne van a munkavállalóknak mind a négy típusa: 1) a napi ingázók, 2) azok, akik munkavállalásuk ideje alatt Magyarországon laknak, ezért nem naponta, hanem ritkábban járnak haza, 3) a magyarországi telephelyủ cégek közvetlen alkalmazásában állók, valamint 4) a szlovákiai telephelyủ munkaerő-kölcsönző cégek alkalmazásában állók.

A 30 ezer munkavállaló rétegződését is csak becsülni tudjuk. Területi szempontból vizsgálva $\mathrm{kb}$. kétharmaduk Nyugat-Szlovákia határ menti járásaiból, a magyarok és szlovákok által vegyesen lakott dunaszerdahelyi, komáromi, érsekújvári és lévai járásból származik. A fentebb említett négy típust szempontul véve, a rendelkezésünkre álló adatokból arra következtethetünk, hogy ebben a térségben a szlovákiai munkaerő-kölcsönzö cégek alkalmazottai vannak enyhe többségben, akik egyben napi ingázók. 2007 decemberében ugyanis a négy leginkább érintett járásból 
Hardi Tamás - Lampl Zsuzsanna: Határon átnyúló ingázás a szlovák-magyar határtérségben. Tér és Társadalom, 22. 2008. 3. 109-126. p.

összesen 9780 személy állt magyarországi cég közvetlen alkalmazásában - a dunaszerdahelyi járásból 2 200, a komáromi járásból 6000 , az érsekújvári járásból 1200 , a lévai járásból pedig 380 munkavállaló ${ }^{1}$. A többiek, vagyis nagyjából 10 000-10 200 személy szlovákiai munkaerö-kölcsönzö cégen keresztül dolgozott Magyarországon. A Közép-és Kelet-Szlovákiában élö kb. 10 ezer munkavállalónak az emlitett szempontok szerinti megoszlásáról nincsenek számszerü információink, csupán feltételezzük, hogy esetükben is hasonló tendenciák érvényesülnek, mint Nyugat-Szlovákiában.

Esettanulmányunk célcsoportját olyan napi ingázók képezik, akik szintén egy szlovákiai munkaerő-kölcsönző cég alkalmazottai. Pozsonyi bejegyzésủ cégröl van szó, amely a lévai járásban fekvő Ipolyságról naponta 300 embert szállít autóbuszokkal Magyarországra. Önkitöltős kérdőivünkkel az összes ingázót megszólítottuk. A visszaérkezett kérdöívekböl 195 felelt meg a feldolgozás követelményeinek, bár hozzá kell tennünk, hogy ez a 195 személy sem válaszolt maradéktalanul az összes kérdésre. Értesüléseink szerint azonban még Szlovákiában nem készült ilyen felmérés az ingázó magyarországi munkavállalók körében, így mindenképpen fontosnak tartjuk az amúgy érdekes és tanulságos eredmények közzétételét.

\section{A minta jellemzése}

A válaszadók többsége a lévai és a szomszédos nagykürtösi járásban él (az utóbbi már Közép-Szlovákiához tartozik). Egyharmaduk városi (Ipolyság, Nagykürtös, Léva), kétharmaduk a környékbeli falvak lakója (Ipolynyék, Ipolyvisk, Csáb, Palást, Felsötúr, Inám, Ipolyszakállos, Rakonca). A válaszadók 71\%-át nők, 29\%-át férfiak alkották. Átlagéletkoruk 34 év, a legfiatalabb 19, a legidősebb 55 éves. Korcsoportok szerinti megoszlásuk jelzi (3. ábra), hogy az 50. életév egyfajta határt képez: míg a negyvenesek csaknem egyharmadát alkotják a mintának, addig 50 éven felüli ingázó már csak elvétve akad. A nemek és korcsoportok kombinációjából az derül ki, hogy míg a férfiak között a 18-30 évesek (53\%) és a 41-50 évesek (30\%) vannak túlsúlyban, $\mathrm{s}$ kisebb a 31-40 évesek jelenléte, a nök korcsoportos eloszlása kiegyensúlyozottabb. Külön-külön nagyjából egyharmaduk tartozik az első három korcsoportba, bár közöttük is a legfiatalabbak vannak a legtöbben.

A válaszadók közül minden negyedik nőtlen/hajadon. 55\%-uk házas, 10\%-uk élettársi viszonyban él. A minta kétharmadát 3-5 tagú családok alkotják. 36\%-uknak egy kiskorú, 25\%-uknak két kiskorú gyermeke van.

Iskolázottságukat tekintve a középfokú végzettségúek vannak túlsúlyban (92\%), ebből legalább 64\%-uk érettségi bizonyítvánnyal rendelkezik ${ }^{2}$. Mindenképpen a szakképesítéssel rendelkezők alkotnak többséget, azaz a szakmunkásképzőt (26\%) és szakközépiskolát (56\%) végzettek. A férfiak iskolázottabbak: $64 \%$-uk rendelkezik szakközépiskolai érettségivel, a nők körében ez az arány 53\%. Ugyanakkor a férfiakhoz képest a nők között kétszeres a szakmunkások részaránya. A korcsoportonkénti elemzés azt mutatja, hogy minél fiatalabb a megkérdezett, annál inkább jellemző rá a szakközépiskolai, $s$ annál kevésbé a szakmunkási végzettség. 
Hardi Tamás - Lampl Zsuzsanna: Határon átnyúló ingázás a szlovák-magyar határtérségben.

Tér és Társadalom, 22. 2008. 3. 109-126. p.

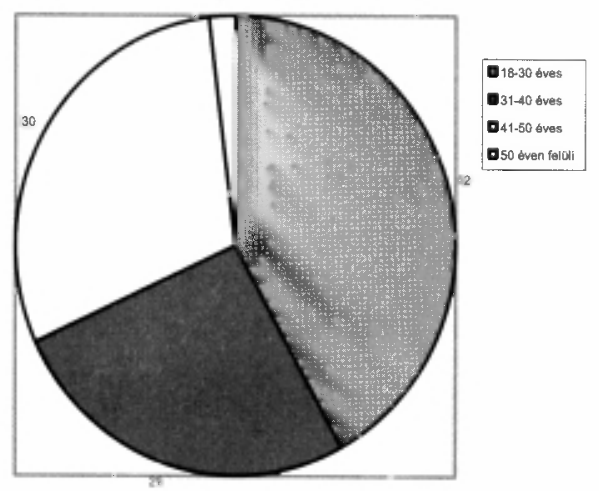

Forrás: Foglalkoztatotti kérdőívek (2008).

A továbbiakban vegyük szemügyre, milyen volt a megkérdezettek munkaeró-piaci státusza, mielött Magyarországon kezdtek dolgozni. Beleszámítva azon 10\%-ukat, akik nem válaszoltak, de akikről más válaszok kapcsán okkal feltételezhetjük, hogy munkanélküliek voltak, a következö képet kapjuk: 73\%-uk foglalkoztatott, 14\%-uk munkanélküli, 13\%-uk inaktív volt. A foglalkoztatottak döntő többségét (70\%) az alkalmazottak alkották, az inaktívak között a tanulók és a gyermeküket gondozó, munkahellyel nem rendelkező anyák csoportja volt a legnépesebb. Az iskolai végzettség hatása ennél a kis mintánál nem mutatható ki, egyébként pedig a többség iskolai végzettségtől függetlenül alkalmazotti státuszban dolgozott. A minta gerincét a korábban Szlovákiában beosztottként dolgozó fizikai munkások alkotják: elsósorban a nem mezőgazdasági szférában alkalmazott fizikai munkások ( $22 \%$ szakmunkás, $38 \%$ betanított munkás, $8 \%$ segédmunkás), valamint a mezőgazdasági munkások (7\%).

Ezek az emberek jelenleg valamennyien legális alkalmazottak, fizetésüket a szlovákiai munkaerö-kölcsönző cégtöl kapják Szlovákiában. 84\%-uk a váci Zollner Kft.-ben dolgozik, a többiek Balassagyarmaton. A leggyakrabban említett szakmák: operátor, szalagmunkás, vizuális ellenőr, minőségi ellenőr, gépszerelö, varrónő, asztalos, de sokan csak annyit írtak, hogy munkás, szakmunkás.

Összehasonlítva a megkérdezettek korábbi szlovákiai státuszát a jelenlegivel elmondhatjuk, hogy akárcsak korábban Szlovákiában, döntő többségük Magyarországon is munkás: háromnegyedük betanított munkás, 10\%-uk szakmunkás. Semmiképp sem tủnik tehát úgy, hogy lecsúsztak volna a társadalmi ranglétrán. Épp ezért figyelemreméltó, hogy $85 \%$-uk azt mondta, nem talált a végzettségének megfelelö munkát, s csupán 14\%-uk dolgozik a képzettségének megfeleló pozícióban. 
Igaz, a megkérdezettek egyharmada ezt nem nehezményezi, mert saját bevallásuk szerint az alulképzett munkáért Magyarországon magasabb fizetést kapnak, mint otthon a képzettségüknek megfelelö munkáért. Úgy túnik azonban, hogy a többiek (52\%) mintha alsóbbrendủ munkának tartanák a mostanit a korábban Szlovákiában végzett munkánál, holott a tények ismeretében objektíven nézve nem igazán van rá okuk. Mindenesetre ezekből a finom jelzésekből arra következtethetünk, hogy az ingázók körében létezik egy ilyesfajta belső feszültség.

\section{A magyarországi munkavállalás}

Egy ember kivételével, aki 1996-tól dolgozik Magyarországon, a többiek a 2000-es évek közepétől vállalnak itt munkát. Válaszaik alapján a munkavállalás két hulláma rajzolódik ki: az egyik 2004-ben, vagyis az EU-tagság idején kezdődött (45\%-ukat érinti), a másik 2007-ben, amikortól 55\%-uk dolgozik Magyarországon. A magyarországi munkavállalás lehetőségéről személyes kapcsolataikon (36\%), a munkaügyi hivatalon keresztül (27\%) és a szlovákiai cég toborzásával (22\%) értesültek.

A megkérdezettek döntó többsége (78\%) most dolgozik elöször Magyarországon. Csupán 38-an (20\%) mondták, hogy nem ez az első munkavállalásuk, de azt, hogy korábban hányszor és hány hónapig került erre sor, nem nagyon akarták elárulni. Csak tizenheten válaszoltak: közülük 14 személy a mostanit megelözỏen egy alkalommal dolgozott Magyarországon, hárman pedig több alkalommal. Ezeknek a munkavállalásoknak az idötartama egy hónaptól öt évig terjedt.

Első munkavállalása óta a megkérdezettek 87\%-a folyamatosan Magyarországon dolgozik. 96\%-uk fóállásban, a többiek mellékállásban, illetve időszaki munkát végeznek. 61\%-uk egész évben Magyarországon dolgozik, a többiek ennél rövidebb időszakokban. Az átlagos munkaidő heti 40 óra, amely háromnegyedükre jellemző. A lakóhelytól a magyarországi munkahelyig számított elérési idő átlagosan 67 perc. A megkérdezettek 54\%-a legfeljebb egy órát utazik, a többieknek ennél tovább tart az út (a leghosszabb 3 óra, amit egy személy említett).

Felmérésünk egyik legfontosabb kérdése, hogy mi késztette a válaszadókat a magyarországi munkavállalásra. A megadott tényezők közül egyiknek sem volt kimagaslóan nagy jelentősége, de a következők azért fontos szerepet játszottak: a magasabb jövedelem (36\%), a kedvezöbb munkakörülmények (15\%), az, hogy Szlovákiában, illetve a szakmájában nem tudott elhelyezkedni (15\% és $11 \%)$, ki kellett egészíteni az otthoni keresetet (6\%). A magyarországi munkavállalást tehát nem olyan „magasabb" szempontok hívták elö, mint a szakmai karrierépítés vagy a nemzeti elkötelezettség, s önmagában nem is olyan nyilvánvaló tényezöknek köszönhetó, mint a földrajzi közelség, jobb közlekedés vagy a magyar nyelvtudás. A magyarországi munkavállalást egész egyértelmûen a több pénz és az elhelyezkedés lehetősége motiválta. Az előbbit elsősorban azok preferálták, akik Szlovákiában is dolgoztak, az utóbbit pedig a munkanélküliek. A magasabb jövedelem elsődleges motiváló erejét az is mutatja, hogy a megkérdezettek $52 \%$-a csak addig akar Magyarországon 
dolgozni, amíg ez anyagilag megéri (30\%-uk hosszú távon is Magyarországon, a többiek amint lehet, Szlovákiában akarnak elhelyezkedni).

Ezek után jogosan kíváncsiskodunk, amikor tudni akarjuk, vajon mennyit keresnek az ingázók. Az igazán jó kérdés persze az lenne, hogy mindent összevetve tényleg többet keresnek-e, mint Szlovákiában, de ahhoz, hogy erre válaszolhassunk, nagyon sok adatot kellene összehasonlítanunk, az adott szakmák jövedelmétől egészen a fogyasztói kosárig. Erre azonban egyrészt most nines lehetőségünk, másrészt pedig elhisszük a megkérdezetteknek, hogy valóban megéri nekik Magyarországon dolgozni. Annál is inkább, mert saját becslésük szerint átlagosan 20\%-kal keresnek többet Magyarországon, mint Szlovákiában.

$\mathrm{Az}$ ugyanolyan munkát végző magyar állampolgár havi nettó jövedelmét átlagosan 86 560Ft-ra saccolták, vagyis 10 ezer Ft-tal többre a saját átlagfizetésüknél, amely 75 312Ft. A megkérdezettek havi nettó átlagjövedelme egyébként 60 ezer és 90 ezer $\mathrm{Ft}$ között mozog. Ennél többet 10 személy említett (a maximum 120 ezer Ft volt) ${ }^{3}$.

Ha a megkérdezetteket havi nettó jövedelmük szerint 75 ezer Ft alatt és 75 ezer Ft felett keresőkre csoportosítjuk, akkor 44\%-uk az első csoportba, 56\%-uk a második csoportba tartozik.

A válaszadók háztartásának átlagos havi nettó jövedelme 147 153Ft. Ha abból indulunk ki, hogy a megkérdezettek nagyrészt négytagú családban élnek, ahol egy vagy két kereső van, akkor elmondható, hogy a havi nettó átlagjövedelemnek megfelelö összeg kb. dupláját keresik meg ketten. Ettől átlagosan kb. 120 ezer Ft-tal többre vágynak, ugyanis a család megfelelő életszinvonalához saját bevallásuk szerint átlagosan $267511 \mathrm{Ft}$-ra lenne szükségük. Ezek után nem csodálkozhatunk, hogy a megkérdezettek háromnegyede (78\%) azt válaszolta, hogy nem tud spórolni, s csupán $22 \%$-uknak nyílik lehetősége megtakarításra.

Maradjunk azonban még egy rövidke elemzés erejéig a havi jövedelemnél. A korcsoportok és az iskolai végzettség szerint nem tapasztalunk különbségeket, ami arra utal, hogy valószínủleg nem az számít, hány éves az alkalmazott és milyen az iskolázottsága, hanem az, hogy milyen munkát végez (ez persze nem okvetlenül független az iskolázottságtól, de a két változó közötti kapcsolat ezen a mintán nem mutatható ki). Nemek szerint viszont szignifikáns különbségek mutatkoznak. A havi nettó jövedelem két szintjét figyelembe véve azt látjuk, hogy a férfiak jobban keresnek, mint a nök. A férfiak 26\%-a keres 75 ezer Ft-nál kevesebbet, 74\%-uk pedig ennél többet. A nőknek viszont csupán a fele keres többet 75 ezer Ft-nál. Ez valószinüleg a férfiak és a nök által végzett szakmák különbözőségével függ össze. A férfiak általában operátori, gépszerelői, villanyszerelői munkakörben dolgoznak, a nők inkább szalagmunkások - vagyis a férfiak a szakmunkások, a nők a betanított munkások. S ezen a ponton újra érvényesülhetne az iskolázottság hatása, hiszen korábban említettük, hogy a férfiak iskolázottabbak a nőknél, de nem érvényesül. Még a férfiaknál sem - a mintában a kevésbé iskolázott férfiak többet keresnek az iskolázottabbaknál. Hogy ez véletlen-e, vagy pedig Magyarországon az iskolázottságnak a felsorolt munkák esetében nincs jelentősége, nyitott kérdés. 
A nettó havi jövedelem kihat a spórolási lehetöségekre. Azok közül, akik 75 ezer Ft-nál kevesebbet keresnek, nagyjából csupán minden ötödik (18\%) tud félretenni, a 75 ezer Ft-nál többet keresők közül viszont minden negyedik. Az összefüggés a másik oldalról megközelítve is érvényes: a takarékoskodni tudók kétharmada keres 75 ezer Ft-nál többet, egyharmaduk 75 ezer Ft-nál kevesebbet.

A fogyasztás Szlovákiában koncentrálódik. Felsoroltunk 13 területet a napi élelmiszer-bevásárlástól egészen a turisztikai szolgáltatásokig, $\mathrm{s}$ egyértelmúen kiderült, hogy ezeket szinte kizárólag lakóhelyükön vagy a környező nagyvárosban (amely a lévaiak és az ipolyságiak esetében egyben lakóhelyük is) veszik igénybe. Magyarországot elvétve említették, $\mathrm{s}$ akkor is csak a turisztikai szolgáltatások és a vendéglátóhelyek kapcsán.

\section{Vélemények, tapasztalatok}

A megkérdezettek többsége a magyarországi munkahellyel kapcsolatban nem említ sem pozitív, sem negatív megkülönböztetést. Ugyanakkor $28 \%$-uk említett olyan dolgokat, amelyeket a pozitív megkülönböztetés kategóriájába soroltak. Pedig, ha elolvassuk a megjegyzéseiket, rájövünk, hogy igazából nem is pozitív diszkriminációról, hanem sokkal inkább emberségről, barátságos hozzáállásról és a jól végzett munka elismeréséröl tanúskodnak. „Értékelik a munkást, a munkáját”, „segítőkészek és emberszeretők”, „kedvesek, közvetlenek”, „mindenki köszön mindenkinek”, „nagyon szeretnek a magyar lányok és a fönököm a jó munkámért”, ,a magyarok kedvesebbek, szimpatikusabbak”, „tudják értékelni a munkámat szóban és pénzben is" stb. Erre minden negyedik munkavállaló felfigyel, amiböl arra következtethetünk, hogy számukra korábban nem ez volt a természetes, nem ilyen munkahelyi légkörhöz szoktak.

Ugyanakkor a válaszadók 30\%-a negatív megkülönböztetést is tapasztal. Ez leginkább abban nyilvánul meg, hogy szerintük a magyarországiak nem szeretik a szlovákokat, s mivel öket is annak tekintik - bár ők nem azok, hanem szlovákiai magyarok -, öket sem szívlelik. E téren persze nem lehet figyelmen kívül hagyni azt sem, hogy a válaszadók 9\%-a a munkahelyén, közvetlen munkája során szlovákul szól egymáshoz, mely alapján a magyarországiak a „nyelvében él a nemzet” egyébként ez esetben is jogos feltételezéséből kiindulva, szlováknak tartják őket (ezzel nem azt akartuk mondani, hogy akkor megbocsátható az utálatos magatartás). Továbbá a magyarországiak attól félnek, hogy a „szlovákok” elorozzák előlük a munkát. „Betolakodónak hívtak, szlováknak neveztek”, „letótoztak”, „nehéz a beilleszkedés, éreztetik veled, hogy szlovák vagy”, „szlovák állampolgárkẻnt több az elvárás", „a szlovákokra hagyják a nehezebb munkát" stb.

Mindent összevetve az ingázók 56\%-a szembesült valamilyen problémával magyarországi munkavállalása során. A problémák sokrétủek: ilyen maga az ingázás (16\%), a családi kapcsolatok sérülése a távollét miatt (6\%), de leginkább a munkahelyi beilleszkedés, amellyel minden negyedik válaszadónak volt ilyen-olyan gondja. Egyrészt 
fŏleg az eltérő munkakultúra és munkahelyi elvárások miatt (6\%), másrészt az általában eltéró szokások és gondolkodásmód miatt $(10 \%)$, s újra említették a negatív diszkriminációt is (6\%). Minden bizonnyal ezek a tapasztalatok is közrejátszanak a munkavállalói szándék jövőbeli alakulásában. Abban, hogy aránylag alacsony (30\%) a hosszú távon/véglegesen Magyarországon dolgozni akarók részaránya, s abban, hogy a munkavállalók 94\%-a nem akar Magyarországra költőzni. A többség tehát nemcsak, hogy a szülöföldjén akar élni, de ott is akar dolgozni. Viszont az előforduló rossz tapasztalatok - talán éppen az ugyancsak előforduló jó tapasztalatoknak (is) köszönhetően - nem befolyásolják a magyarországi magyarokról alkotott képet. A megkérdezettek ugyanis a magyarországi magyarok tíz legjellemzőbb tulajdonságának a következőket tartják: vidámak, tiszták, barátságosak, segitökészek, vendégszeretők, együttérzők, magabiztosak, anyagiasak, kreatívak, precízek ${ }^{4}$. A magyarországiakról alkotott kép tehát egyértelmủen pozitív. Negatív tulajdonságokat is felsoroltunk, de ezeket kevésbé tartották rájuk jellemzőnek.

A munkahellyel kapcsolatos véleményeken, tapasztalatokon túl megkértük a legalább három éve folyamatosan Magyarországon dolgozókat, hogy értékeljék, menynyiben változtak az elmúlt időszakban a munkavállalás körülményei. Többségük úgy látja, hogy jelenleg

- nincs akkora szükség a szlovák munkaerőre, mint korábban (58\%), viszont a szlovákiai munkaerö megbecsültsége inkább nött (53\%), mint csökkent;

- nehezebb munkát találni (67\%);

- a vásárlóértéket alapul véve rosszabbul fizetnek (76\%);

- keményebben meg kell dolgozni a fizetésért ((77\%).

A munkakörülmények változását illetően a huzamosabb ideje ingázók fele javulást, másik fele rosszabbodást tapasztal. Arra a kérdésre pedig, hogy a mai szlovákiai viszonyok között jobban megéri-e Magyarországon dolgozni, mint korábban, „,öntetlen állás" született: a válaszadók egyik fele szerint megéri, a másik fele szerint nem. Azok a válaszadók, akik szerint még most is érdemes Magyarországon dolgozni, többnyire a korábban Szlovákiában munkanélküliek közül kerülnek ki. Nagyon valószínü, hogy odahaza most sem tudnának elhelyezkedni, tehát számukra még mindig a magyarországi munkavállalás a mentőöv. Azok a válaszadók pedig, akik szerint már nem éri meg ingázni, nagyrészt azonosak a korábbi szlovákiai állásukat a jobb kereset reményében magyarországi munkavállalásra váltókkal. Ők ma rosszabbul járnak, mint korábban, mivel egyrészt a bérszint változatlan maradt, másrészt a forint-korona árfolyam számukra kedvezötlen alakulása, valamint az árak rohamos növekedése miatt csökkent a keresetük reálértéke. Tehát vannak, akik örülnek, hogy Magyarországon dolgozhatnak, mert más lehetőségük nem nagyon van, mások pedig nem örülnek ugyan, mert a magyarországi munkavállalás kezdeti elönyei veszni látszanak, de úgy tünik, egyelöre nekik sincs más lehetöségük.

Kutatásaink során kiderült, hogy a határon átnyúló munkavállalás jelensége a térségben nem csupán konjunkturális elemektől függ. Válaszadóink fontosnak érezték ugyan a másik oldalon elérhető magasabb béreket, de ugyanolyan fontos a munka- 
Hardi Tamás - Lampl Zsuzsanna: Határon átnyúló ingázás a szlovák-magyar határtérségben. Tér és Társadalom, 22. 2008. 3. 109-126. p.

hely térbeli közelsége is. İgy nyugodtan elmondhatjuk, hogy térségünkben az ingázó munkavállalás nem hagyományos nemzetközi migráció, hanem klasszikus város-vidék kapcsolatokon alapszik. Intenzitását, volumenét befolyásolják az elérhető bérek, de látni kell, hogy az ingázók többsége az alacsonyabban fizetett tevékenységi körökben dolgozik, ahol a bérkülönbségek nem különösebben fognak változni a két ország között. Az euró bevezetése szlovák oldalon nyilván vissza fogja vetni némileg a mozgást, de eltüntetni nem fogja. Érdemes lenne e tekintetben is a szakmai egyeztetéseket tovább folytatni, s a munkaügy még szélesebb együttmüködését szorgalmazni a szakképzés, átképzés stb. területén is, $\mathrm{s}$ ezzel a határon átnyúló munkaerö-piaci térségeket megerösíteni.

\section{Jegyzetek}

${ }^{1}$ Forrás: Eures Danubius konferencia, Dunaszerdahely, 2008. március 14.

${ }^{2}$ A szakközépiskolai $(55,6 \%)$ és gimnáziumi $(9,6 \%)$ végzettségủekről van šzó. A szakmunkásképzőt végzetteknél $(26,4 \%)$ ez nem derül $\mathrm{ki}$, ugyanis vannak érettségivel végződő és érettségit nem biztosító szakmunkásképzők.

${ }^{3}$ Ezek az összegek alacsonynak tünnek a hivatalosan közzétett 2007-es havi keresetekhez képest - segédmunkás 99 924Ft, betanított munkás $137365 \mathrm{Ft}$, szakmunkás $154327 \mathrm{Ft}$, mester $241362 \mathrm{Ft}$ (Forrás: Eures Danubius konferencia, Dunaszerdahely, 2008. március 14.)

4 A szlovákiai magyarok legjellemzőbb tíz tulajdonsága a megkérdezettek szerint: tiszák, vidámak, szorgalmasak, együttérzők, segítőkészek, barátságosak, vendégszeretők, hüségesek, alaposak, precízek.

\section{Irodalom}

Amin, A. (1996) An institutional perspective on regional economic development. - International Journal of Urban and Regional Research. 23. 365-378. o.

Aydemir, A.-Borjas, G.J. (2006) A Comparative Analysis of the Labor Market Impact of International Migration: Canada, Mexico, and the United States. NBER Working Paper Series 12327. National Bureau of Economic Research, Cambridge.

Hardi T. (2005) Határon átnyúló ingázás, munkavállalás az osztrák-magyar határtérségben. - Tér és Társadalom. 2. 65-82. o.

Hárs Á. (2006) A szlovák és magyar határ menti régió a Duna két oldalán. Megvalósíthatósági tanulmány. Kopint-Datorg Zrt., Budapest.

Krakover, Sh. (1997) Boundary Openness Model Applied to Israel, Egypt and Gaza strip Tri-border Area. Paper presented at the European Regional Science Association Summer Institute, Are.

Niebuhr, A-Stiller, S. (2002) Integration Effects in Border Regions - A Survey of Economic Theory and Empirical Studies. Paper presented: Congress of the European Regional Science Association „From Industry to Advenced Services." August 27-31. Dortmund.

Shuttleworth, I. (2007) Reconceptualising local labour markets in the context of cross-border and transnational labour flows: The Irish example. - Political Geography. 26. 968-981. o. 
Hardi Tamás - Lampl Zsuzsanna: Határon átnyúló ingázás a szlovák-magyar határtérségben.

Tér és Társadalom, 22. 2008. 3. 109-126. p.

126 Hardi Tamás - Lampl Zsuzsanna

TÉT XXII. évf. 2008

\title{
TRANSBORDER COMMUTING ON THE SLOVAKIAN- HUNGARIAN BORDER REGION
}

\author{
TAMÁS HARDI - ZSUZSANNA LAMPL
}

Our study examines the cross-border commuting. The study wants to divide it from commuting within the state and from the international labour migration as well. The examination shall include the impact on local labour market and then the ongoing processes in SlovakianHungarian border region shall be represented according to empirical data.

The transborder commuting has a 30 years old tradition on the Slovakian-Hungarian border region. Both countries have been an EU-member since 2004, and this new situation can help make the organisation of transborder economic contacts easier. Due to the very good geographical position of this region, multinational companies, such as Philips, Siemens, IBM, Nokia etc. are already seizing on the opportunities of the transborder region, and are expanding in this region. There is a growing automotive cluster in Hungary (Audi, Suzuki), in Slovakia (VW, Peugeot, Citroën). The growing region needs labour force. The differences in the earnings and in the possibility of works make an always stronger commuting between the border areas.

In Hungary, for Gyór-Moson-Sopron and Komárom-Esztergom counties, the nearby Hungarian-inhabited areas in Slovakia are important sources of labour force for the industrial branches serving economic boom, also, subcontractors are often found there (e. g. cleaning businesses etc.).

In this paper we would like to present an empirical research (2008) in this topic. In our research we asked the commuters in a questionnaire about the changes of their life, decisions, work-place etc. We have made interweaves with employers, employment agencies etc. We examine the development of the number of commuters in the last decade, the motivation of workers and employer, and the change of the labour market under the effect of the growing flows and we would like show the effects, that this flows make in the economy of border regions. 